\title{
Adaptative Leaf Morphology of Eurya japonica Thunb. (Ternstroemiaceae) in Serpentine Areas
}

\author{
Masayuki Shiba ${ }^{1}$, Tomoki Tate ${ }^{2} \&$ Tatsuya Fukuda $^{1}$ \\ ${ }^{1}$ Graduate School of Integrative Science and Engineering, Tokyo City University, Tokyo, Japan \\ ${ }^{2}$ Graduate School of Integrated Arts and Sciences, Kochi University, Nankoku, Kochi, Japan \\ Correspondence: Masayuki Shiba, Graduate School of Integrative Science and Engineering, Tokyo City \\ University, 1-28-1 Tamazutsumi, Setagata, Tokyo, Japan. E-mail: msykshiba48@gmail.com
}

\author{
Received: December 10, $2021 \quad$ Accepted: January 19, $2022 \quad$ Online Published: January 25, 2022 \\ doi:10.5539/jps.v11n1p10 \\ URL: https://doi.org/10.5539/jps.v11n1p10
}

\begin{abstract}
Serpentine soils are known to affect plant growth and plants in these soils have morphological and anatomical modifications. Comparative leaf morphology and anatomy studies of Eurya japonica Thunb. was conducted between serpentine and inland (control) areas. Our morphological analyses revealed that the individuals in the serpentine areas had significantly smaller and thicker leaves than those in the inland areas. Our anatomical analyses showed that the smaller leaves of serpentines had decreased numbers of cells, and their thicker leaves contributed to the increased height of epidermal cells, palisade tissue, and spongy tissue. Furthermore, the stomatal size of serpentines was significantly smaller than those from the inland areas. We concluded that $E$. japonica adapted to the serpentine areas by decreasing leaf size due to low levels of nutrients, by thickening the leaves to store water and reducing the stomatal size to minimize water loss via gas exchange.
\end{abstract}

Keywords: adaptation, anatomy, Eurya japonica, leaf, morphology, serpentine, stomata

\section{Introduction}

Soil conditions play dominant roles in terrestrial ecosystems, and nutrient mineralization in soil could affect biodiversity. Adaptation to edaphic factors such as soil physical, chemical, and biological characteristics have long been considered important components in plant distribution, diversification, and speciation (Kruckeberg, 1951; 1967). Serpentine soils occur in small patches along fault lines where igneous rocks appear and are characterized by abiotic factors such as low calcium-to-magnesium ratio, high heavy metal concentrations, nutrient deficiency, and low moisture retention, leading to sharp transitions in abiotic conditions at the boundaries of serpentine patches (Brady et al., 2005). Therefore, serpentine areas are a unique land type that hinder habitation by many plants, but they lead to the creation of new endemic species, including Leontopodium hayachinense (Takeda) H. Hara et Kitam. (Asteraceae), Primula yuparensis Takeda (Primulaceae), Hypericum tosaense Makino (Hypericaceae), Spiraea nipponica Maxim. var. ogawae (Nakai) Yamanaka (Rosaceae) (Kitamura, 1981; Yamazaki, 1981; Momiyama, 1982; Ohashi, 1989). Various unique plant flora have been reported in serpentine areas in Japan (Hara, 1937; Taniguchi, 1958; Yamanaka, 1973, 1974; Nakata, \& Kojima, 1987; Kitamura, 1993), and it has been reported that even if the plant can invade and grow in serpentine areas, they often undergo morphological and anatomical modifications. For example, a comparative study using the serpentine ecotype and non-serpentine of Adenophora triphylla (Thunb.) A. DC. var. japonica (Regel) H. Hara (Campanulaceae) revealed that the former species had thinner stems and narrower leaves (Ohga et al., 2012). Moreover, it is interesting that this species adapted to the drought stress of serpentine conditions by reducing stomatal density (Ohga et al., 2012). Such stomatal changes have also been reported in the serpentine-endemic Aster hispidus Thunb. var. leptocladus (Makino) Okuyama (Asteraceae) (Hayakawa et al., 2012; Kumekawa et al., 2013) and have been considered a plant adaptive mode in serpentine areas. Moreover, the fact that the reduced stomatal density was also found among different lineages suggested that this modification was likely an adaptation to serpentine areas. However, these studies were conducted using herbaceous species, and it remains unclear whether tree species growing in serpentine areas have acquired their own adaptations. Tree species can store water absorbed in various tissues (Goldstein et al., 1984; Goldstein et al., 1998; Borchert, 1994), meaning that trees in serpentine areas could have different stomatal adaptation strategies than herbaceous species. Despite the functional significance of leaf shape in environmental adaptation (Nicotra et al., 2011), few aspects of leaf 
shape have been linked directly to adaptive outcomes.

Eurya japonica Thunb. belongs to Ternstroemiaceae based on APG III (Haston et al., 2009) and is approximately $1-3.5 \mathrm{~m}$ tall and is a broad-leaved, evergreen, woody perennial that is widely distributed throughout Japan, from Honshu to Ryukyu, and Korea (Tsuyama, 1989). This species grows along the margins of evergreen forests, and Yamanaka (1959) reported that this species also grew in some serpentine areas of Shikoku, Japan. It is doubtful whether E. japonica is accompanied by the above-mentioned modifications in the serpentine condition. As for the morphological and anatomical modification of this species to adapt to different environmental conditions, Shiba et al. (2021) recently indicated that the leaves of this species along rivers were significantly smaller to adapt to sudden flooding and strong river currents after heavy rain. Moreover, the stomatal density of riverside populations was significantly higher in response to soil moisture, which appears to correspond to riverside conditions (Shiba et al., 2021). This report explored adaptations of E. japonica to other environmental conditions, with morphological and anatomical modifications. However, it is unclear whether E. japonica undergoes morphological and anatomical modifications to adapt to serpentine conditions. Therefore, we characterized the variation in the leaves of E. japonica using morphological and anatomical analyses.

\section{Method}

We collected samples from five localities in Kochi Prefcture, Japan. These localities were named as follows: two serpentine areas (Ikou and Kagami) and three inland areas (Okina, Shigeto, and Noichi) (Figure 1; Table 1). These localities are indicated in Figure 1 and Table 1. E. japonica was analyzed in a total of 60 individuals from the serpentine areas (30 from Ikou and 30 from Kagami) and 93 individuals from the inland areas (30 from Okina, 33 from Shigeto, and 30 from Noichi) (Figure 2).

Shiba et al. (2021) reported methods of morphological and anatomical analyses in E. japonica. Therefore, we followed these methods in this study.

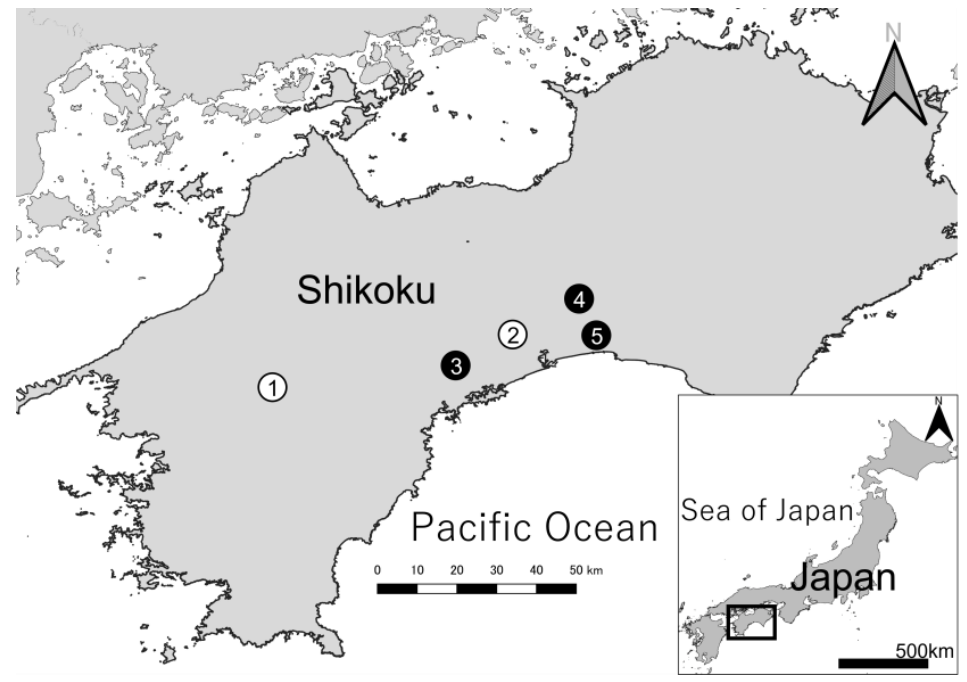

Figure 1. Sampling localities in this study

White and black circles indicate serpentine and inland (control) populations, respectively. Number in circles corresponds to that given in Table 1

Table 1. Sampling localities used in this study

\begin{tabular}{|c|c|c|c|c|c|}
\hline Type & \multicolumn{2}{|c|}{ Locality name \& number* } & Locality & \multicolumn{2}{|c|}{ Latitude and longitude } \\
\hline \multicolumn{6}{|c|}{ Serpentine } \\
\hline & Ikou & 1 & Ikou, Yusuhara-cho, Takaoka-gun, Kochi Pref. & $33^{\circ} 27^{\prime} \mathrm{N}$ & $132^{\circ} 50^{\prime} \mathrm{E}$ \\
\hline & Kagami & 2 & Kagami-ohri, Kochi City, Kochi Pref. & $33^{\circ} 35^{\prime} \mathrm{N}$ & $133^{\circ} 29^{\prime} \mathrm{E}$ \\
\hline \multicolumn{6}{|c|}{ Inland (control) } \\
\hline & Okina & 3 & Okina, Hidaka-mura, Takaoka-gun, Kochi Pref. & $33^{\circ} 30^{\prime} \mathrm{N}$ & $133^{\circ} 20^{\prime} \mathrm{E}$ \\
\hline & Shigeto & 4 & Kashinotani, Tosayamada-cho, Kami City, Kochi Pref. & $33^{\circ} 41^{\prime} \mathrm{N}$ & $133^{\circ} 39^{\prime} \mathrm{E}$ \\
\hline & Noichi & 5 & Ohtani, Noichi-cho, Konan City, Kochi Pref. & $33^{\circ} 34^{\prime} \mathrm{N}$ & $133^{\circ} 42^{\prime} \mathrm{E}$ \\
\hline
\end{tabular}

*: locality no. corresponds to that given in Figure 1. 


\section{Results}

We analyzed the leaf morphology of Eurya japonica using morphological and anatomical approaches. A summary of the morphological measurements is presented in Table 2. We calculated the mean leaf length, width, thickness, and angle of the leaf base for each individual. Leaf length and width in the serpentine populations tended to be smaller than those of the inland (control) populations, and leaf area in the former was significantly smaller than that in the latter. To detect morphological differentiation in serpentine areas, the leaf index values were calculated as the ratio of leaf length to leaf width, based on Tsukaya (2002). If the results of comparingthese leaf index values between serpentine and inland populations showed a significant difference, it indicates that the population with the large value has relative narrow leaves (Tsukaya, 2002). No significant difference between the serpentine and inland populations was detected in the leaf index. Furthermore, there was no significant difference in the angle of the leaf base between the populations, indicating that they have similar leaf silhouettes. However, our results indicated that leaves in the serpentines had significantly thicker leaves than those in the inland areas.
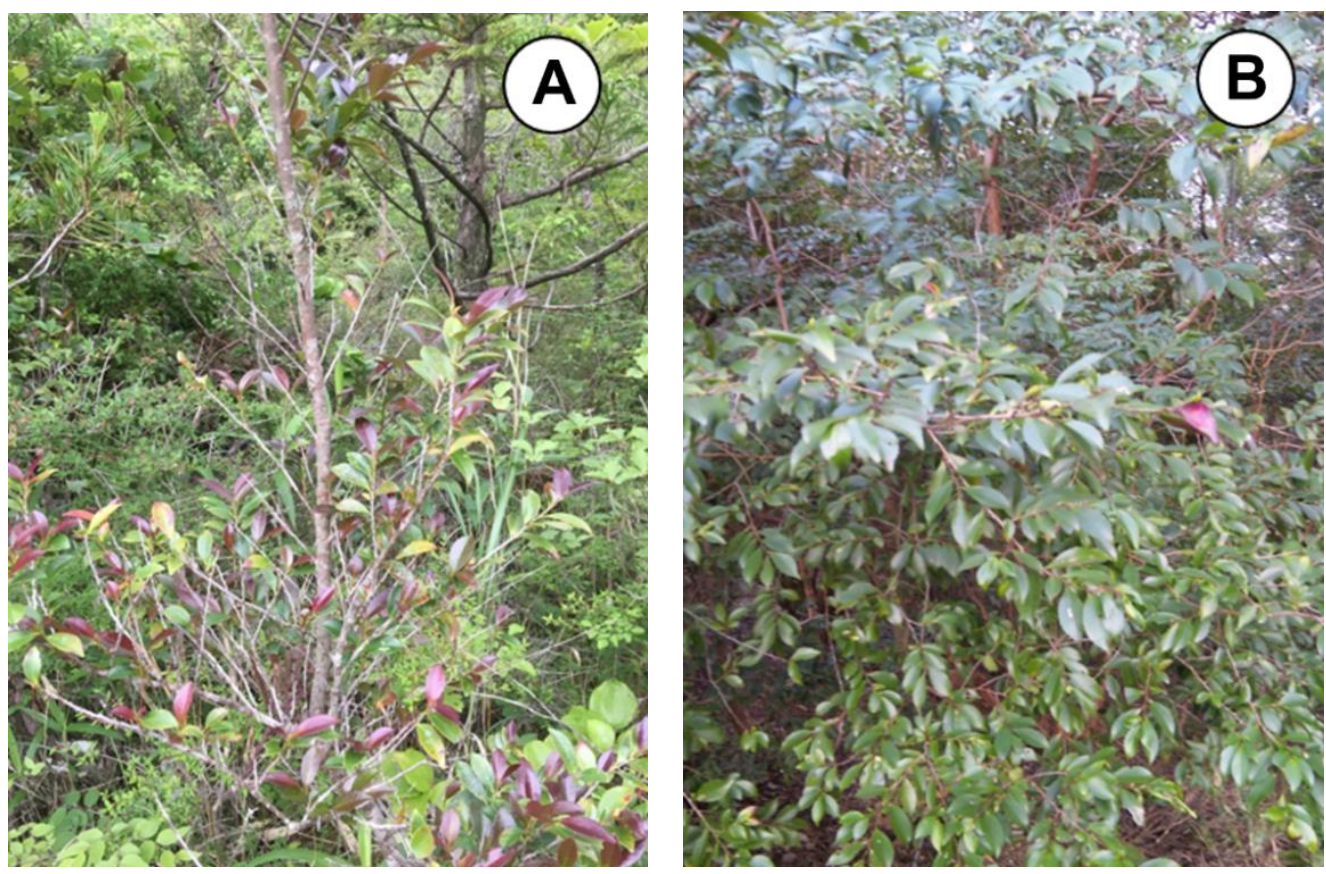

Figure 2. Eurya japonica Thunb. A: serpentine (Kagami), B: inland (Noichi)

Table 2. Leaf morphology (average \pm standard error) of Eurya japonica

\begin{tabular}{|c|c|c|c|c|c|c|c|c|c|c|}
\hline & \multicolumn{4}{|l|}{ Serpentine } & \multicolumn{6}{|l|}{ Inland (control) } \\
\hline & Ikou & & Kagami & & Okina & & Shigeto & & Noichi & \\
\hline length (mm) & $45.52 \pm 1.13$ & $\mathrm{c}$ & $50.22 \pm 0.95$ & $\mathrm{~b}$ & $53.58 \pm 1.25$ & $a b$ & $55.00 \pm 1.13$ & $\mathrm{a}$ & $54.01 \pm 1.13$ & $a b$ \\
\hline width (mm) & $19.86 \pm 0.45$ & $\mathrm{c}$ & $17.76 \pm 0.49$ & $\mathrm{~d}$ & $21.77 \pm 0.36$ & $a b$ & $20.84 \pm 0.33$ & $\mathrm{bc}$ & $22.92 \pm 0.48$ & $\mathrm{a}$ \\
\hline $\operatorname{size}\left(\mathrm{mm}^{2}\right)$ & $911.83 \pm 37.09$ & $\mathrm{~b}$ & $900.81 \pm 36.43$ & $\mathrm{~b}$ & $1,177.75 \pm 41.92$ & $\mathrm{a}$ & $1149.85 \pm 27.62$ & $\mathrm{a}$ & $1,252.92 \pm 47.81$ & $\mathrm{a}$ \\
\hline leaf index* & $2.31 \pm 0.06$ & $\mathrm{c}$ & $2.88 \pm 0.07$ & $\mathrm{a}$ & $2.47 \pm 0.05$ & $\mathrm{bc}$ & $2.66 \pm 0.05$ & $a b$ & $2.37 \pm 0.04$ & $\mathrm{c}$ \\
\hline angle of leaf base $\left(^{\circ}\right)$ & $62.71 \pm 1.47$ & $\mathrm{a}$ & $52.75 \pm 1.47$ & $\mathrm{~b}$ & $53.58 \pm 1.18$ & $\mathrm{~b}$ & $55.10 \pm 1.02$ & $\mathrm{~b}$ & $62.89 \pm 1.66$ & $\mathrm{a}$ \\
\hline thickness $(\mu \mathrm{m})$ & $283.83 \pm 8.27$ & $\mathrm{a}$ & $269.13 \pm 5.57$ & a & $183.85 \pm 6.34$ & $\mathrm{~b}$ & $191.43 \pm 8.90$ & $\mathrm{~b}$ & $173.00 \pm 7.90$ & $\mathrm{~b}$ \\
\hline
\end{tabular}

Columns marked by different letters differ significantly according to the Tukey's HSD test $(p<0.05)$.

*: Tsukaya (2002)

We calculated the mean epidermal cell size using the length and width of a cell on both adaxial and abaxial sides of the leaf measured from SUMP samples of this species (Table 3; Figure 3). The results showed that the cell length and width and the cell size on both adaxial and abaxial sides of the leaf were not significantly different between serpentine and inland populations, suggesting that the difference in leaf size was caused not by the difference in the number of cells on sides of the leaf. In addition, the results of measuring the height of epidermal 
cells, palisade tissue, and spongy tissue that contributes to the thickness of the leaves using the longitudinal section of the leaf are shown in Table 4 and Figure 4. The results showed that the heights of epidermal cells, palisade tissue, and spongy tissue were significantly different between serpentine and inland populations.

We measured and calculated the mean stomatal size (guard cell area, based on guard cell pair length and width) and density using SUMP samples of serpentine and inland areas of E. japonica from all localities we examined (Table 5 and Figure 5). Although the stomatal size of serpentines was significantly smaller than that of the inland populations, stomatal density did not differ significantly.

Table 3. Anatomical measurements (average \pm standard error) of epidermal cell in Eurya japonica

\begin{tabular}{|c|c|c|c|c|c|c|c|c|c|c|}
\hline & \multicolumn{4}{|l|}{ Serpentine } & \multicolumn{6}{|c|}{ Inland (control) } \\
\hline & Ikou & & Kagami & & Okina & & Shigeto & & Noichi & \\
\hline \multicolumn{11}{|c|}{ adaxial surface } \\
\hline length $(\mu \mathrm{m})$ & $20.98 \pm 0.24$ & $\mathrm{a}$ & $20.13 \pm 0.19$ & $a b$ & $20.14 \pm 0.24$ & $a b$ & $20.13 \pm 0.27$ & $a b$ & $19.93 \pm 0.25$ & $\mathrm{~b}$ \\
\hline width $(\mu \mathrm{m})$ & $21.05 \pm 0.26$ & $\mathrm{a}$ & $20.21 \pm 0.17$ & $a b$ & $20.39 \pm 0.29$ & $a b$ & $19.91 \pm 0.20$ & $\mathrm{~b}$ & $20.03 \pm 0.32$ & $\mathrm{~b}$ \\
\hline $\operatorname{size}\left(\mu \mathrm{m}^{2}\right)$ & $444.35 \pm 10.67$ & $\mathrm{a}$ & $409.77 \pm 7.19$ & $a b$ & $411.94 \pm 9.59$ & $a b$ & $401.69 \pm 7.76$ & $\mathrm{~b}$ & $411.94 \pm 9.59$ & $\mathrm{~b}$ \\
\hline \multicolumn{11}{|c|}{ abaxial surface } \\
\hline length $(\mu \mathrm{m})$ & $20.51 \pm 0.16$ & a & $18.97 \pm 0.24$ & $\mathrm{~b}$ & $19.32 \pm 0.18$ & $a b$ & $19.70 \pm 0.66$ & $a b$ & $19.85 \pm 0.22$ & $a b$ \\
\hline width $(\mu \mathrm{m})$ & $18.42 \pm 0.14$ & $\mathrm{a}$ & $17.08 \pm 0.19$ & $\mathrm{~b}$ & $17.03 \pm 0.14$ & $\mathrm{~b}$ & $18.01 \pm 0.22$ & $\mathrm{a}$ & $17.99 \pm 0.22$ & $\mathrm{a}$ \\
\hline $\operatorname{size}\left(\mu \mathrm{m}^{2}\right)$ & $378.77 \pm 4.74$ & a & $328.16 \pm 7.81$ & $\mathrm{~b}$ & $328.79 \pm 3.77$ & $\mathrm{~b}$ & $354.63 \pm 12.45$ & $a b$ & $356.44 \pm 3.66$ & $a b$ \\
\hline
\end{tabular}

Columns marked by different letters differ significantly according to the Tukey's HSD test $(p<0.05)$.

Table 4. Anatomical measurements (average \pm standard error) of mesophyll tissues using longitudinal section in Eurya japonica

\begin{tabular}{|c|c|c|c|c|c|c|c|c|c|c|}
\hline & \multicolumn{4}{|l|}{ Serpentine } & \multicolumn{6}{|c|}{ Inland (control) } \\
\hline & Ikou & & Kagami & & Okina & & Shigeto & & Noichi & \\
\hline epidermal cell at adaxial side $(\mu \mathrm{m})$ & $28.15 \pm 0.50$ & a & $23.03 \pm 0.64$ & $\mathrm{~b}$ & $17.65 \pm 0.63$ & $\mathrm{c}$ & $13.28 \pm 0.70$ & $d$ & $17.18 \pm 0.58$ & $\mathrm{c}$ \\
\hline palisade tissue $(\mu \mathrm{m})$ & $102.60 \pm 3.96$ & a & $87.80 \pm 2.94$ & $\mathrm{~b}$ & $61.58 \pm 3.45$ & $\mathrm{c}$ & $63.20 \pm 3.90$ & $\mathrm{c}$ & $59.88 \pm 3.36$ & $\mathrm{c}$ \\
\hline spongy tissue $(\mu \mathrm{m})$ & $130.30 \pm 4.04$ & a & $138.13 \pm 2.70$ & a & $90.43 \pm 3.82$ & $\mathrm{bc}$ & $105.38 \pm 6.33$ & $\mathrm{~b}$ & $82.30 \pm 5.26$ & $\mathrm{c}$ \\
\hline epidermal cell at abaxial side $(\mu \mathrm{m})$ & $22.78 \pm 0.57$ & $\mathrm{a}$ & $20.18 \pm 0.34$ & $\mathrm{~b}$ & $14.20 \pm 0.63$ & $\mathrm{c}$ & $9.58 \pm 0.49$ & $\mathrm{~d}$ & $13.65 \pm 0.34$ & $\mathrm{c}$ \\
\hline
\end{tabular}

Table 5. Anatomical measurements (average \pm standard error) of stomata in Eurya japonica

\begin{tabular}{lllllllllll}
\hline & Serpentine & \multicolumn{10}{c}{ Inland (control) } \\
\hline & Ikou & & Kagami & & Okina & Shigeto & Noichi & \\
\hline length $(\mu \mathrm{m})$ & $18.74 \pm 0.26$ & bc & $17.68 \pm 0.23$ & c & $19.58 \pm 0.21$ & ab & $20.10 \pm 0.18$ & a & $20.83 \pm 0.61$ & a \\
width $(\mu \mathrm{m})$ & $4.89 \pm 0.02$ & b & $4.92 \pm 0.03$ & b & $5.12 \pm 0.06$ & a & $5.22 \pm 0.05$ & a & $5.22 \pm 0.07$ & a \\
size $\left(\mu \mathrm{m}^{2}\right)$ & $91.99 \pm 1.53$ & c & $87.03 \pm 1.36$ & c & $100.17 \pm 1.64$ & b & $104.75 \pm 1.34$ & a & $107.02 \pm 1.93$ & a \\
density $\left(\mathrm{N} / \mu \mathrm{m}^{2}\right)$ & $213.39 \pm 5.13$ & c & $251.64 \pm 4.85$ & ab & $259.19 \pm 4.90$ & a & $243.33 \pm 6.49$ & ab & $233.26 \pm 5.67$ & bc \\
\hline
\end{tabular}

Columns marked by different letters differ significantly according to the Tukey's HSD test $(p<0.05)$.
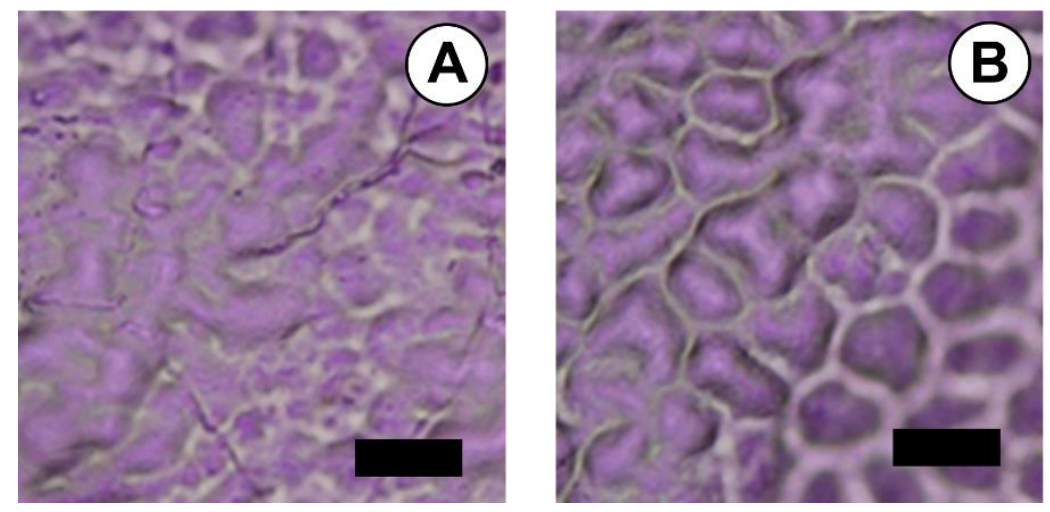

Figure 3. Epidermal cell on adaxial surface

A: serpentine (Kagami), B: inland (Noichi). Bar $=30 \mu \mathrm{m}$ 

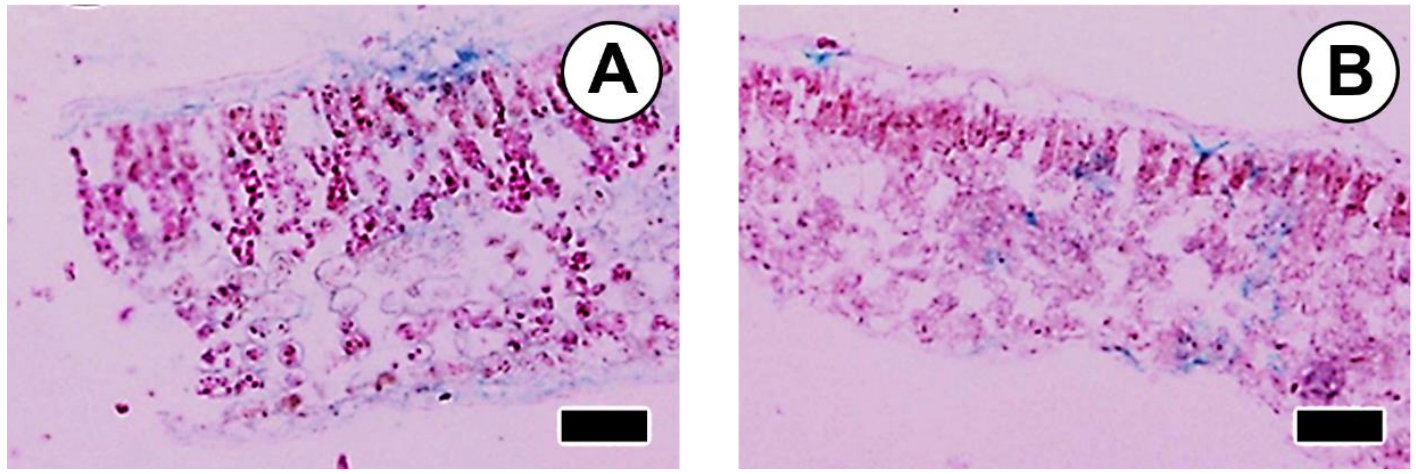

Figure 4. Cross-section of leaf

A: serpentine (Kagami), B: inland (Noichi). Bar $=50 \mu \mathrm{m}$
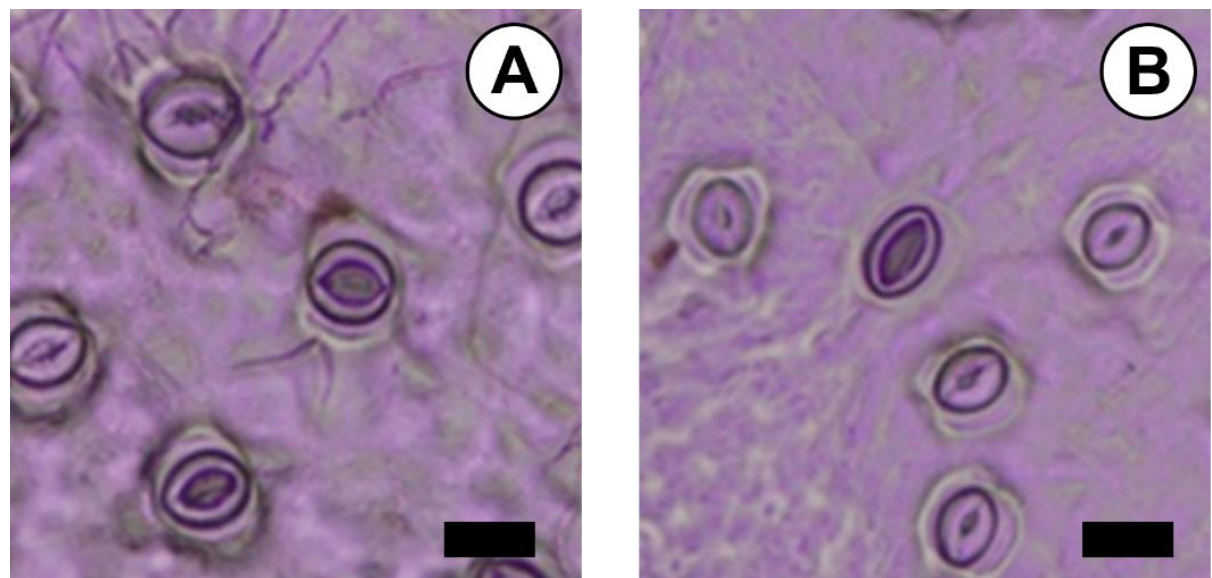

Figure 5. Stomata on abaxial surface

A: serpentine (Kagami), B: inland (Noichi). Bar $=20 \mu \mathrm{m}$

\section{Discussion}

The morphological characteristics of an edaphic ecotype may be the result of a physiological adaptation to the environment and serpentine soils, which have an excess of magnesium, chromium, and nickel and a deficiency of plant nutrients such as potassium, phosphorus, and calcium, that adversely affect plant growth (Kruckeberg, 1954). In particular, high magnesium content inhibits calcium uptake in plants, due to antagonistic uptake between the two cations (Gardner \& Macnair, 2000; Brady et al., 2005). Therefore, plants that grow in serpentine soils must adapt to their environment by developing plant bodies capable of detoxifying heavy metals and tolerating low nutrient levels (Kruckeberg, 1954; Brady et al., 2005). The characteristic vegetation in serpentine

outcrops is associated with the presence of edaphic endemic species, and the morphological characteristics may differ from those of ancestral species in non-serpentine areas (Kruckeberg, 1954). In fact, previous studies have indicated that serpentine-adapted plants have narrow leaves (Hayakawa et al., 2012; Ohga et al., 2012; Kumekawa et al., 2013, 2016), indicating that these reductions could be a response to an edaphic environment that exhibits nutrient deficiencies in serpentine soils (Kruckeberg, 1954). Our results indicated that E. japonica in the serpentine populations had thicker leaves and smaller stomata than those of the inland populations (Table 2 ), suggesting that $E$. japonica had been morphologically and anatomically modified to adapt to serpentine soils. Moreover, it is interesting that E. japonica did not develop narrow leaves in serpentine areas although previous studies of serpentine ecotypes have reported decreased leaf size due to low nutrient levels in serpentine areas (Ohga et al., 2012; Kumekawa et al., 2013). Therefore, our results revealed that the leaf size of E. japonica was not affected by low levels of nutrients. However, the leaves were significantly thicker in the serpentine area, which is discussed below.

Thickening of the leaves plays an important role in maintaining water potential when the water supply is low 
(Coneva \& Chitwood, 2018). Ogburn and Edwards (2010) indicated that a variety of morphological and anatomical features that could vary with the aridity of the habitat underlie this adaptive feature. In fact, some studies have reported that taxa with thick leaves were found in low water supply areas, such as coastal areas (Hayakawa et al., 2012; Ohga et al., 2012). Serpentine soils are also poor in soil organic matter accumulation, which decreases water-holding capacity, and these soils can cause drought stress in plants (Kruckeberg, 1954; Gardner \& Macnair, 2000; Hughes et al., 2001). Therefore, our finding that E. japonica developed thicker leaves in the serpentine area indicated that this species might morphologically adapt to the dryness of serpentine soils. On the cellular level, leaf thickness has been broadly associated with increased cell size (Watson, 1942), which promotes water storage (Becker, 2007), and some studies have reported that the differentiation of leaf thickness is directly related to the height of palisade cells (Garnier \& Laurent, 1994; Roderick et al., 1999; Sack \& Frole, 2006; John et al., 2013). For example, Coneva et al. (2017) reported that palisade cells were linked to increased leaf thickness in a desert-adapted wild species.

Furthermore, our anatomical results showed that the differentiation of E. japonica leaf thickness in serpentine areas was attributed to an increase in the height of epidermal, palisade, and spongy cells. Although our anatomical results were considered to be a morphological adaptation to the dry environment in serpentine areas, it has been shown that the differentiation in leaf cell height affects other functions. Oguchi, Hikosaka and Hirose (2005) and Terashima et al., (2011) reported that the increased height of palisade cells led to improved uptake of carbon dioxide and improved photosynthesis in thick leaves. Moreover, the shape of palisades has also been functionally linked to a more efficient distribution of light throughout the leaf (Brodersen et al., 2008; Brodersen \& Vogelmann, 2010). From these studies, thicker leaves were correlated with rapid growth and drought conditions (Edwards et al., 2014). However, our anatomical results indicated that the stomatal size of E. japonica in serpentine areas was smaller than that in the control localities. Stomata are small pores formed by a pair of guard cells on the epidermis of leaves, which control the water loss in transpiration and the carbon dioxide uptake for photosynthesis (Hetherington \& Woodward, 2003; Franks \& Beerling, 2009). Smaller stomata sizes reduce water loss, but there is also a decrease in the absorption efficiency of carbon dioxide. Therefore, our anatomical results suggested that E. japonica in the serpentine areas adapted through not only thicker leaves for storing water but also by reduced stomatal size, at the expense of photosynthesis, to minimize water loss. From these results, we concluded that E. japonica experienced significant stress in the serpentine areas and it could not grow without these anatomical differentiations. In addition, future comparative studies of morphological and anatomical modifications of other organs, such as stem and root, between inland areas and serpentine areas will boost up our understanding of the adaptation of E. japonica into serpentine areas.

Shiba et al. (2021) indicated that six independent riverside populations of E. japonica experienced differentiation, including smaller leaves and higher stomata density. Moreover, populations of E. japonica are located in a small mosaic area of Kochi Prefecture in accordance with serpentine outcrops. The riverside or serpentine ecotypes of this species are found in Kochi Prefecture and its neighboring areas. Although these ecotypes of E. japonica might have been derived from Kochi Prefecture and its neighboring areas, it is doubtful whether allopatric ecotypes have expanded their distribution through a single origin or in parallel origin at each location. In fact, some studies indicated that the origin of the ecotype involves an assessment of its being an ecotype derived from the result of parallel evolution (Nicholls \& McNeilly, 1982; Wolf, Howe, \& Hamrick, 2000; Nyberg Berglund, Dahlgren, \& Westerbergh, 2003; Yokoo et al., 2009). Further molecular phylogenetic analyses of this species will provide a practical scenario to verify the origin of these E. japonica ecotypes.

\section{Acknowledgments}

We wish to thank Drs. Ohga K (Kochi University), Kumekawa Y (Ehime University), Hayakawa H (Museum of Natural and Environmental History, Shizuoka), and Yokoyama J (Yamagata University) for providing much help. This study was partly supported by a Grant-in-Aid for Scientific Research from the Ministry of Education, Science and Culture of Japan.

\section{References}

Becker, B. (2007). Function and evolution of the vacuolar compartment in green algae and land plants (Viridiplantae). International Review of Cytology, 264, 1-24. https://doi.org/10.1016/S0074-7696(07)64001-7

Borchert, R. (1994). Soil and stem water storage determine phenology and distribution of tropical dry forest trees. Ecology, 75, 1437-1449. https://doi.org/10.2307/1937467

Brady, K. U., Kruckeberg, A. R., \& Bradshaw, H. D. Jr. (2005). Evolutionary ecology of plant adaptation to serpentine soils. Annual Review of Ecology, Evolution and Systematics, 36, 243-266. 
https://doi.org/10.1146/annurev.ecolsys.35.021103.105730

Brodersen, C. R., Vogelmann, T. C., Williams, W. E., \& Gorton, H. L. (2008). A new paradigm in leaf-level photosynthesis: direct and diffuse lights are not equal. Plant, Cell and Environment, 31, 159-164. https://doi.org/10.1111/j.1365-3040.2007.01751.x

Brodersen, C. R., \& Vogelmann, T. C. (2010). Do changes in light direction affect absorption profiles in leaves? Functional Plant Biology, 37, 403-412. https://doi.org/10.1071/FP09262

Coneva, V., Frank, M. H., Balaguer, M. A. L., Li, M., Sozzani, R., \& Chitwood, D. H. (2017). Genetic architecture and molecular networks underlying leaf thickness in desert-adapted tomato Solanum pennellii. Plant Physiology, 175, 376-391. https://doi.org/10.1104/pp.17.00790

Coneva, V., \& Chitwood, D. H. (2018). Genetic and developmental basis for increased leaf thickness in the Arabidopsis Cvi ecotype. Frontiers in Plant Science, 9, 322. https://doi.org/10.3389/fpls.2018.00322

Edwards, E. J., Chatelet, D. S., Sack, L., \& Donoghue, M. J. (2014). Leaf life span and the leaf economic spectrum in the context of whole plant architecture. Journal of Ecology, 102, 328-336. https://doi.org/10.1111/1365-2745.12209

Franks, P. J., \& Beerling, D. J. (2009). Maximum leaf conductance driven by $\mathrm{CO}_{2}$ effects on stomatal size and density over geologic time. Proceedings of the National Academy of Sciences of the United States of America, 106, 10343-10347. https://doi.org/10.1073/pnas.0904209106

Gardner, M., \& Macnair, M. (2000). Factors affecting the co-existence of the serpentine endemic Mimulus nudatus Curran and its presumed progenitor, Mimulus guttatus Fisher ex DC. Biological Journal of Linnean Society, 69, 443-459. https://doi.org/10.1111/j.1095-8312.2000.tb01218.x

Garnier, E., \& Laurent, G. (1994). Leaf anatomy, specific mass and water content in congeneric annual and perennial grass species. New Phytologist, 128, 725-736. Retrieved from https://www.jstor.org/stable/2558379

Goldstein, G., Andrade, J. L., Meinzer, F. C., Holbrook, N. M., Cavelier, J., Jackson, P., \& Celis, A. (1998). Stem water storage and diurnal patterns of water use in tropical forest canopy trees. Plant, Cell and Environment, 21, 397-406. https://doi.org/10.1046/j.1365-3040.1998.00273.x

Goldstein, G., Meinzer, F., \& Monasterio, M. (1984). The role of capacitance in the water balance of Andean giant rosette species. Plant, Cell and Environment, 6, 649-656. https://doi.org/10.1111/1365-3040.ep11614612

Hara, H. (1937). Preliminary report on the flora of southern Hidaka, Hokkaido (Yezo). XX. The Botanical Magazine, 51, 142-149. https://doi.org/10.15281/jplantres1887.51.142

Haston, E., Richardson, J.E., Stevens, P.F., Chase, M.W., \& Harris, D. J., (2009). The Linear Angiosperm Phylogeny Group (LAPG) III: a linear sequence of the families in APG III. Botanical Journal of the Linnean Society, 161, 128-131. https://doi.org/10.1111/j.1095-8339.2009.01000.x

Hayakawa, H., Tunala, Minamiya, Y., Ito, K., Gale, S., Yokoyama, J., ... Fukuda, T. (2012). Comparative study of leaf morphology in Aster hispidus Thunb. var. leptocladus (Makino) Okuyama (Asteraceae). American Journal of Plant Sciences, 3, 110-113. http://dx.doi.org/10.4236/ajps.2012.31011

Hetherington, A. M., \& Woodward, F. I. (2003). The role of stomata in sensing and driving environmental change. Nature, 424, 901. https://doi.org/10.1038/nature01843

Hughes, H., Bachmann, K., Smirnoff, N., \& Macnair, M. R. (2001). The role of drought tolerance in serpentine tolerance in the Mimulus guttatus Fisher ex DC. complex. South African Journal of Science, 97, 581-586. Retrieved from https://hdl.handle.net/10520/EJC97240

John, G. P., Scoffoni, C., \& Sack, L. (2013). Allometry of cells and tissues within leaves. American Journal of Botany, 100, 1936-1948. https://doi.org/10.3732/ajb.1200608

Kitamura, S. (1981). Leontopodium. In Y. Satake, J. Ohwi, S. Kitamura, S. Watari \& T. Tominari (Eds.), Wild Flowers of Japan III: herbacerous plant (including dwarf subshrubs) (pp. 205-206). Heibonsha Tokyo. (In Japanese).

Kitamura, S. (1993). Studies on serpentine flora of Japan. In S. Kitamura (Ed.), Distribution and Differentiation of Plants (pp.146-202). Hoikusha Publishing, Osaka, Japan (in Japanese).

Kruckeberg, A. R. (1951). Intraspecific variability in the response of certain native plant species to serpentine 
soil. American Journal of Botany, 38, 408-419. https://doi.org/10.2307/2438248

Kruckeberg, A. R. (1954). The ecology of serpentine soils III. Plant species in relation to serpentine soils. Ecology, 35, 267-274. https://doi.org/10.2307/1931126

Kruckeberg, A. R. (1967). Ecotypic response to ultramafic soils by some plant species of northwestern United States. Brittonia, 19, 133-144. https://doi.org/10.2307/2805271

Kumekawa, Y., Miyata, H., Ohga, K., Hayakawa, H., Yokoyama, J., Ito, K., ... Fukuda, T. (2013). Comparative analyses of stomatal size and density among ecotypes of Aster hispidus (Asteraceae). American Journal of Plant Sciences, 4, 524-527. https://doi.org/10.4236/ajps.2013.43067

Kumekawa, Y., Yoshioka, K., Kubose, Y., Fujimoto, H., Uemoto, C., Ozaki, Y., ... Fukuda, T. (2016). A new form of Aster hispidus var. leptocladus (Asteraceae). Journal of Japanese Botany, 92, 49-51. http://id.ndl.go.jp/bib/000000011666

Momiyama, Y. (1982). Hypericum. In Y. Satake, J. Ohwi, S. Kitamura, S. Watari \& T. Tominari (Eds.), Wild Flowers of Japan II: herbaceous plants (including dwarf subshrubs) (pp. 113-119). Heibonsha, Tokyo. (In Japanese).

Nakata, M., \& Kojima, S. (1987). Effects of serpentine substrate on vegetation and soil development with special reference to Picea glehnii forest in Teshio District, Hokkaido, Japan. Forest Ecology and Management, 20, 265-290. https://doi.org/10.1016/0378-1127(87)90084-3

Nicholls, M. K., \& McNeilly, T. (1982). The possible polyphyletic origin of copper tolerance in Agrostis tennis (Gramineae). Plant Systematics and Evolution, 140, 109-117. https://doi.org/10.1007/BF02407292

Nicotra, A. B., Leigh, A., Boyce, C. K., Jones, C. S., Niklas, K. J., Royer, D. L., \& Tsukaya, H. (2011). The evolution and functional significance of leaf shape in the angiosperms. Functional Plant Biology, 38, 535-552. https://doi.org/10.1071/FP11057

Nyberg Berglund, A. B., Dahlgren, S., \& Westerbergh, S. (2003). Evidence for parallel evolution and site-specific selection of serpentine tolerance in Cerastium alpinum during the colonization of Scandinavia. New Phytologist, 161, 199-209. https://doi.org/10.1046/j.1469-8137.2003.00934.x

Ohashi, H. (1989). Spiraea. In Y. Satake, H. Hara, S. Watari \& T. Tominari (Eds.), Wild Flowers of Japan I: woody plants (pp. 181-185). Heibonsha, Tokyo. (In Japanese).

Ohga, K., Muroi, M., Hayakawa, H., Yokoyama, J., Ito, K., Tebayashi, S., ... Fukuda, T. (2012). Morphological and anatomical analyses of the serpentine ecotype of Adenophora triphylla var. japonica (Campanulaceae). Journal of Plant Studies, 1, 180-187. http://dx.doi.org/10.5539/jps.v1n2p180

Ogburn, R., \& Edwards, E. J. (2010). The ecological water-use strategies of succulent plants. Advances in Botanical Research, 55, 179-225. https://doi.org/10.1016/B978-0-12-380868-4.00004-1

Oguchi, R., Hikosaka, K., \& Hirose, T. (2005). Leaf anatomy as a constraint for photosynthetic acclimation: differential responses in leaf anatomy to increasing growth irradiance among three deciduous trees. Plant, Cell and Environment, 28, 916-927. https://doi.org/10.1111/j.1365-3040.2005.01344.x

Roderick, M. L., Berry, S. L., Noble, I. R., \& Farquhar, G. D. (1999). A theoretical approach to linking the composition and morphology with the function of leaves. Functional Ecology, 13, 683-695. https://doi.org/10.1046/j.1365-2435.1999.00368.x

Sack, L., \& Frole, K. (2006). Leaf structural diversity is related to hydraulic capacity in tropical rain forest trees. Ecology, 87, 483-491. https://doi.org/10.1890/05-0710

Shiba, M., Tate, T., \& Fukuda, T. (2021). Rheophytic adaptation of Eurya japonica (Ternstroemiaceae). International Journal of Biology, 13, 65-73. https://doi.org/10.5539/ijb.v13n2p65

Taniguchi, M. (1958). Phytosociological Study of Serpentine Area of Mt. Asama, Mie Pref. Acta Phytotaxonomica et Geobotanica, 17, 122-127. https://doi.org/10.18942/bunruichiri.KJ00001077800

Terashima, I., Hanba, Y. T., Tholen, D., \& Niinemets, Ü. (2011). Leaf functional anatomy in relation to photosynthesis. Plant Physiology, 155, 108-116. https://doi.org/10.1104/pp.110.165472

Tsukaya, H. (2002). The leaf index: heteroblasty, natural variation, and the genetic control of polar process of leaf expansion. Plant and Cell Physiology, 43, 372-378. https://doi.org/10.1093/pcp/pcf051

Tsuyama, T. (1989). Theaceae. In Y. Satake, H. Hara, S. Watari \& T. Tominari (Eds.), Wild Flowers of Japan I: woody plants (pp. 138-147). Heibonsha Tokyo. (In Japanese). 
Watson, R. W. (1942). The mechanism of elongation in palisade cells. New Phytologist, 41, 206-221. https://doi.org/10.1111/j.1469-8137.1942.tb07074.x

Wolf, A. T., Howe, R. W., \& Hamrick, J. L. (2000). Genetic diversity and population structure of the serpentine endemic Calystegia collina Convolvulaceae in northern California. American Journal of Botany, 87, 1138-1146. https://doi.org/10.2307/2656650

Yamanaka, T. (1959). A phytosociological study of serpentine areas in Shikoku, Japan. Bulletin of Faculty of Education, Kochi University, 8, 1-47.

Yamanaka, T. (1973). Sociological studies on the serpentine vegetation. XV. The serpentine vegetation in Shizuoka Prefecture. Bulletin of Faculty of Education, Kochi University, 22, 125-135. (in Japanese).

Yamanaka, T. (1974). Sociological studies on the serpentine vegetation. XVII. Supplementary notes on the serpentine vegetation at low altitudes in Shikoku. Bulletin of Faculty of Education, Kochi University, 23, 21-35. (in Japanese).

Yamazaki, T. (1981). Primura. In Y. Satake, J. Ohwi, S. Kitamura, S. Watari \& T. Tominari (Eds.), Wild Flowers of Japan III: herbaceous plants (including dwarf subshrubs) (pp. 21-24). Heibonsha, Tokyo. (In Japanese).

Yokoo, T., Kobayashi, S., Fujikawa, S., Oginuma, K., Mitsui, Y., Ikeda, H., \& Setoguchi, H. (2009). Genetic structure among and within populations of serpentine endemic Heteropappus hispidus ssp. leptocladus (Compositae). Biochemical Systematics and Ecology, 37, 275-284.

https://doi.org/10.1016/j.bse.2009.04.012

\section{Copyrights}

Copyright for this article is retained by the author(s), with first publication rights granted to the journal.

This is an open-access article distributed under the terms and conditions of the Creative Commons Attribution license (http://creativecommons.org/licenses/by/4.0/). 